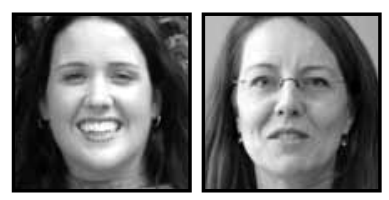

\title{
Informal Learning and Volunteering: The Case of an Unemployed Certified Teacher in Ontario
}

\author{
Jennifer Pearce \& Katina Pollock, Western University
}

\begin{abstract}
Newly certified, unemployed teachers in Ontario, Canada are volunteering in schools as a way to gain access to the teaching profession. This paper reports the case of one volunteer teacher in Ontario who reported informal learning and acquisition of professional knowledge as central to his volunteer experience. Specifically, the participant demonstrated learning in the areas of (1) pedagogy and classroom management and (2) non-instructional duties and responsibilities. Implications for unemployed teachers, teacher education, and administration are discussed.
\end{abstract}

n Ontario, Canada, newly certified teachers are volunteering their services in schools and classrooms in unprecedented numbers. Given the paucity of current research that examines this population in detail, we embarked upon a qualitative study to investigate the experiences of these teachers. What we have found is a diverse and complex relationship with volunteering amongst a small set of teachers. Amid the findings are vivid examples of informal learning. Reported in this paper is a summary of responses from one teacher, Matthew (pseudonym), who represents a particularly rich case of informal learning initiated by volunteer experience. Matthew's case gives us a starting place to discuss professional knowledge that he has acquired through volunteering, and possible implications for teacher education programs and administrators responsible for teacher hiring. 


\section{Context}

\section{Teacher Certification in Ontario}

In Canada, individual provinces govern education, with publicly funded elementary and secondary education overseen by a provincial Ministry. The public school system in Ontario is geographically divided into 72 school boards that are responsible for administering educational programs. The Ontario Ministry of Education educates just over two million students, and employs approximately 114,000 teachers ${ }^{1}$ (Ontario Ministry of Education, 2011).

In order to teach in an Ontario public school, an individual must have completed at a minimum, a three-year undergraduate degree in addition to a one-year teacher education program. Teachers are initially certified to teach in one of three division ranges, consisting of two consecutive, age-based, divisions: Primary-Junior (Kindergarten to Grade 6), Junior-Intermediate (Grade 4 to Grade 10), or IntermediateSenior (Grade 7 to Grade 12). ${ }^{2}$ Once certified by the Ontario College of Teachers (the province's regulatory body for teachers), an individual is granted the OCT (Ontario Certified Teacher) professional designation (Ontario College of Teachers, n.d.). After their initial certification, many teachers take additional courses and programs called Additional Qualifications (AQs) that update and expand professional knowledge (Ontario College of Teachers, n.d.).

Once certified, teachers searching for employment in the province typically apply for positions through online employment sites such as Apply to Education. ${ }^{3}$ Many new teachers in large, urban school boards first find paid employment on an occasional list as "supply" or "substitute" teachers before moving on to long-term or permanent contracts (Ontario College of Teachers, 2011).

\section{Current Teacher Employment Market}

Over the last decade, falling student enrollment and teacher retirement rates, coupled with a relatively constant number of teacher certifications (from new graduates and the arrival of internationally educated teachers), has meant a surplus of teachers in Ontario (Ontario College of Teachers, 2011). The surplus has resulted in growing wait times for newly certified teachers to obtain full-time employment: a teacher who is certified today may wait as long as five years (Mclntyre, 2011), and will experience a mix of unemployment, occasional (supply) teaching, and long-term non-permanent contracts while they wait. Newly certified teachers are using various strategies, including volunteering, in order to compete in the teacher job market, 
which currently has an unemployment rate of 24 per cent (Ontario College of Teachers, 2011).

\section{Conceptual Framework}

This paper seeks to examine unemployed teachers' volunteer work in more detail at the individual level. While there are important and challenging issues associated with certified teachers volunteering, including marginalization (Duggleby, 2007; Pollock, 2010), underemployment (Livingstone, 2010), and position in the professional hierarchy (Pollock, 2008), no study has probed individual perceptions of the volunteer experience for newly certified, unemployed teachers. Learning is of particular interest as it is frequently overlooked in investigations about volunteering (Ilsley, 1990; Schugurensky \& Mundel, 2005) even though in many circumstances, the volunteer is surrounded by opportunities for learning, which are often unplanned and informal (Ilsley, 1990).

This paper situates informal learning in the context of work. Unemployed teachers who volunteer in schools are uniquely suited to speak about learning in this setting as they are positioned at the nexus of two spheres of work: paid employment and volunteer work. While this seems like a contradiction, the individuals in the study are giving their time (volunteering ${ }^{4}$ ) at the site of future paid work. Livingstone (2000) reported that there is a strong association between informal learning and the three spheres of work: paid employment, housework, and community volunteer work. That is, informal learning increases as the amount of time spent at work increases. Given the unique context of work for these teachers, exploring how informal learning manifests itself may provide some important insights.

\section{Methodology}

The single case reported here is from a larger qualitative study completed by one of the authors (Pearce, forthcoming) that explored the volunteer work of unemployed teachers in Southwestern Ontario, Canada. Newly certified teachers who had no paid teaching employment of any kind were interviewed $(n=6)$ in an effort to find out how these teachers understand their volunteer work. Semi-structured interviews (60-90 minutes in length) were conducted that specifically asked about the activities 
that they were engaged in while they volunteered in schools, as well as their perceptions of work and learning. Given the potential to explore the informal learning of this distinct group, the questions that were asked in the semi-structured interview that pertained to learning were adapted from the National Survey of Learning and Work (Livingstone et al., 2004), which probed volunteers about their formal and informal learning activities.

One interviewee in particular spoke acutely about the knowledge and skills he gained through his volunteer work. It was apparent that informal learning was central, rather than peripheral, in his experience. This piqued our interest and made it a thought-provoking case to report on in the context of informal learning. This paper will briefly summarize his responses, and demonstrate that he acquired explicit and tacit professional knowledge from his volunteer work.

\section{Participant}

At the time of the interview (Fall 2011), Matthew was a single male in his late twenties, aspiring to teach in a full-time classroom in an elementary school within a large, mostly urban school board in Southwestern Ontario. He was working full-time as a manager of a retail location, which paid well and provided job security, as he had a good relationship with the owner of the store.

\section{Professional work.}

In 2009, Matthew graduated from an Ontario teacher certification program (Bachelor of Education, B.Ed) with a certification to teach in the Primary-Junior division. He applied to the occasional teacher list immediately after graduation in the spring of 2009 but was unsuccessful. During the remainder of 2009 and into 2010, Matthew completed two additional AQ courses, which certified him to teach all grades in the public education system (Kindergarten to Grade 12). In the fall of 2010, Matthew applied to the same occasional teacher list and was unsuccessful once again. At the time of the interview (Fall 2011), nearly one year after his last application, there had not been any additional openings for supply teachers at the school board in which he desired to teach, but he was confident that was going to change in the very near future.

\section{Volunteer experience.}

Matthew began volunteering in a classroom very shortly after graduating from his Bachelor of Education in 2009. While not told explicitly that he was required to volunteer, the sense he received from other teacher candidates, as well as from his 
instructors during his B.Ed, was that volunteering was a good idea; it would help him stay connected in some way to teaching given the growing competition for jobs. Matthew approached the teacher who had supervised him during the practice teaching requirement (or "practicum") of his B.Ed to see if she would take him on as a volunteer. Due to the good rapport they had developed, she agreed to have him volunteer as much as he wanted. Over the course of three school years (April-June 2009, September 2009-June 2010, September 2011 to the time of the interview in Fall 2011), Matthew volunteered approximately one full school day per week, averaging 6-7 hours per day, spending most of his time in a Grade 7 elementary classroom. In total, he has spent approximately 65 days volunteering, contributing over 400 hours. He engaged in a range of activities in the school, from setting up for assemblies to teaching full lessons in the classroom. He described a positive relationship with the classroom teacher he worked with, school staff and administration, as well as students.

\section{Findings}

For Matthew, it appears that his informal learning has led to the acquisition of explicit and tacit professional knowledge in two areas: (1) pedagogy and classroom management, and (2) non-instructional duties and responsibilities of a teacher. First, we will demonstrate that Matthew is learning informally, and then we will discuss examples of the knowledge he has gained in the two identified areas.

According to their preliminary research findings, Schugurensky and Mundel (2005) suggest that the primary mode for learning in volunteer activities is incidental and informal, and results in tacit knowledge (Eraut, 2000). Matthew is no different in this respect. He referenced the value of his volunteer work, which, in particular, allowed him the opportunity to learn beyond his formal teacher education. He mentioned that while the formal education had some value, it was the amount of time he had spent in a school beyond his B.Ed that was the most valuable:

...all of that momentum [gained in the practicums] is gone [by the time it ends]. You have to stop and go back to class, and sit there and learn about things you know don't work [...] or they don't work for you. [With volunteering for three years] the beginning was going in, open-eyed, open-eared and trying to take everything in because it's all really new... and from year to year you grow, and the things that you really needed to think about the first year, you don't have to think about as much anymore, they're kind of more automated. 
Here, Matthew described how his behaviour in a school became more automatic. There is an increased situational understanding (Eraut, 2000) that has been developed over three years of experience in a school. He explained how he approached his volunteer work, taking the opportunity to learn informally, and build on the knowledge that he had acquired in a supportive school environment:

[...] The progression changes from year to year, and you take on new challenges that you wouldn't have had before or wouldn't have been able to do before [...] I have developed an appreciation of what my skills are, what my weaknesses are, [and can] target what I want to work on in the classroom... You can make yourself work on things you're not comfortable with, but you have the safety net of an experienced teacher...so you can't screw up too badly, but the opportunity is there to succeed or not succeed...

From this quotation, we see evidence that Matthew is a reflective practitioner (Schön, 1983), using his volunteer experience to his advantage, which is helping him improve his current and future practice. When asked if his volunteer work makes him a better teacher, Matthew emphatically agreed: "I feel that I have definitely matured more. I have more capability. I have more tools I can draw on from being exposed to them."

Matthew's growing confidence as a teacher is apparent. His confidence likely originates from explicit and tacit knowledge he has gained in two general areas related to teaching: pedagogy and classroom management, and non-instructional duties and responsibilities, which is what we will turn to next.

\section{Pedagogy and Classroom Management}

Several times, Matthew made reference to how he was able to see the application of theories he had learned in his teacher education related to pedagogy and classroom management. For example:

I would go and see how the gym teacher instructs, and see what they do that's different from the other teacher, and when you're going from class to class, it's easier to compare those types of things cause you saw just how they were interacting and how the students were responding, and then you see a different approach and how the students were responding, and you can see the merits in all of the different ways that teachers approach it...so I feel that that was a great thing to see because it's difficult to appreciate how something works in reality when you're learning about it at school, it's just all 
theoretical—so they might say if you encroach on a student's space, they'll stop talking, and it's like, sometimes that works, sometimes that works for one reason, but sometimes it doesn't, but you get to see that play out in reality, which is I think beneficial.

The learning and knowledge acquisition from this example is apparent. Matthew explained the process of how he assimilated practical knowledge about classroom management into the theoretical knowledge he had already obtained. While he did not perceive the value of some of the theoretical work he had to complete, being situated in the school context compelled him to consider what he had learned formally, and use that information when making professional decisions while volunteering. The outcomes of his decisions while in the classroom had real implications, which appear to be a component of the informal learning process taking place during the volunteer experience. In another example, he also explained how volunteering taught him in areas where he did not have preexisting knowledge:

When you're around teachers, you kind of learn how they set up things, and that's something you don't really get when you're at teacher's college. Teacher's college is a very "how to deal with things," it's a base layer of learning, it gives you the building blocks you need to kind of figure out your way when you finally get into a classroom, but it doesn't practically teach you how to manage a day book, or how to sort what needs to be marked immediately from what doesn't. You never get that "real world" application of theory from the classroom. So by seeing an actual teacher being like at the end of the day "I'm going to take this stuff home but not this stuff" and I would mark things during the day so she wouldn't have to take things home, so you kind of figure out kind of the priority stuff and what needs to be marked right away and why — students need feedback on math things immediately, it's very important to take up math right away...

Here, Matthew discussed some of the more nuanced decisions that a teacher must make in an average day that contributes to the long-term performance of the classroom. This differed from the practice teaching that was a part of his B.Ed, which he described as too punctuated, never seeing the lasting outcomes of his professional practice and decisions on individual students and whole classrooms. Volunteering over the course of an entire school year, even though it was only one day per week, compelled Matthew to consider classroom routines and their outcomes in a different way. These are just two examples that demonstrate that Matthew has learned beyond his formal teacher education about facilitating student learning and 
managing student behavior. He discussed many other examples of this, as well as teacher responsibilities that extend beyond the narrow confines of a classroom.

\section{Non-instructional Duties and Responsibilities}

Seventy-six percent of Canadian volunteers reported that they engaged in some sort of learning related to their volunteer work (Livingstone et al., 2004) mostly in the domains of interpersonal and communication skills. Matthew reported learning in these areas during his volunteer work, but also included computers, budgeting and financial management, health and well-being, new equipment, language skills, and increased knowledge about social/political/environmental issues. Certainly a wide range of seemingly unrelated areas, but his answers all related to the teaching profession in some way. For example, his response to learning about health and wellbeing:

...I've always been a person who will volunteer their own time for the sake of personal well-being from time to time... but when you see the responsibility of a teacher [...I realize] that if I get sick, I'll get so far behind, and they [the students] can't accomplish any of the stuff. So it's like life considerations being made regarding your health, but for your job. It's not something I ever really thought about in my regular job. If I'm sick, I don't go...it's not like things will totally fall behind... but that can happen in a classroom.

This response in particular demonstrates that his volunteer experience has exposed him to a reality about teaching. Volunteering in a classroom setting has led Matthew to consider his own health and well-being in a different way that may impact his choices in his day-to-day life, as well as in the future as a classroom teacher. He also articulated an example that pertained to teamwork:

When you are in a school you get to see a lot of the behind-the-scene dynamics that you never get to see when you're a student, on the other side of things, when you're hanging out with the teachers in the staff room, and you hear them talking about a student who wasn't having a good day and what they can do about it, or keep an eye out for it, you get to see a lot of the actual camaraderie and behind-the-scenes work that goes on amongst teachers because you don't ever see that as a student, you always see them on their own, you don't see them collaborating behind the scenes with somebody on something. 
In this example, the knowledge gained is more tacit in nature; Matthew was able to observe the dynamics of teamwork and collaboration, which demonstrates how he might work with his colleagues to solve problems in the future.

Here is one final example Matthew gave when asked about learning related to budgeting and financial management:

...they have a field trip that they do every year, and I have never really seen the process that you have to go through to actually implement a field trip. I mean, you hear about it in teacher's college-you need insurance, you need consent forms, but to actually see it come together, negotiate the bus contracts, figure out the amount of money that needs to be kicked in by the students, what is kicked in by the school...l got to learn how to actually set something like that up.

While still taking place in an informal context, this example represents deliberative learning (Eraut, 2000) about a specific task. Presented with assisting with this task while volunteering, Matthew took the opportunity and became engaged in the process. He actively solicited information about the logistics and has learned how he might go about implementing something similar in the future. Learning in this area expands Matthew's knowledge in relation to activities that extend beyond the classroom that involve other parties, such as school administration and external service providers.

\section{Discussion}

Over three years, Matthew has gained a great deal of explicit and tacit knowledge (Eraut, 2000) related to the teaching profession. That is, knowledge he is able to recognize having, and is able to discuss when probed, as well as knowledge that can be inferred from his responses. His increased confidence and efficacy is evidence that he is building situational recognition and understanding (Eraut, 2000) in the teaching context and is gaining skills towards becoming a more experienced professional (Dreyfus \& Dreyfus, 1986).

Could this knowledge have been gained in another way other than in the volunteer capacity? Certainly, if Matthew had been hired to teach in a classroom immediately after his B.Ed he would have had some similar experiences in his first 
year of teaching and learned informally from these experiences. Unique to volunteering, however, is the opportunity for additional mentoring and valuable professional feedback. In addition, finding full-time employment immediately after certification is unlikely in Ontario at the present time. One might also argue that the knowledge Matthew gained through volunteering could have been acquired through practice teaching during his Bachelor of Education. However, in addition to the feedback from Matthew that the practice teaching sessions were too short, ${ }^{5}$ we also posit that his volunteer experience differs from his prior practice teaching experience, in that he had more control and autonomy over his volunteer work. Livingstone (2001) suggests that those engaged in discretionary spheres of working life engage more actively in informal learning. The high degree to which Matthew reports learning from his volunteer work may reflect the relative amount of autonomy he was given during the experience. Although in some sense this volunteer work is not functionally at his discretion (his perception is that he would be remiss if he did not volunteer), he has found an exceptional situation in which to volunteer: the teachers and administration in the school where Matthew volunteered allowed him some freedom to choose the type of volunteer work he did as well as the flexibility to decide when he could do it. Consequently, because he has volunteered, Matthew has learned some skills and knowledge that will help him be a more effective teacher when he does find paid employment in the profession. In effect, Matthew has more experience now than he did when he finished his B.Ed, even though he has not yet found paid work.

A further question thus remains: is Matthew's volunteer work recognized as legitimate experience when it comes to hiring decisions? Given that he has been passed over twice for an interview at the school board of his choice, one might speculate that it is not. Speculation aside, we can look at the Apply to Education online system where teachers search for jobs, complete individual profiles, and upload their resume and supporting documentation to be viewed by potential employers. Presently, in the "experience" section of the online profile, there is no explicit place to enter volunteer work (although, there is a catchall section dubbed "Other" where one can enter additional information of any type). Looking at Matthew's individual case, and the identified knowledge acquisition he has engaged in while volunteering in the school and classroom, it would be difficult to deny that his volunteer work has given him some sort of teaching "experience." For school boards and school administrators, there could be implications. Careful inspection of resumes for references to volunteer work in schools may assist in finding the more experienced individuals amongst a large group of newly certified candidates. In addition, inquiring about the details of these volunteer activities in interviews may reveal significant proficiency in a number of unexpected areas, akin to what Matthew has described in the interview examined in this paper, due to the informal learning opportunities afforded to these volunteers. 


\section{Conclusion}

Broader structural solutions are needed in Ontario in order to correct the imbalance in the teacher employment market. Ultimately, the "need" to volunteer should not have to exist to gain access to the profession, as it can and does lead to marginalization and exploitation. Matthew has made the best of an unfortunate employment situation; not all new teachers who volunteer find themselves with this type of positive, more "authentic" experience, where a meaningful mentoring relationship can develop. Many struggle with fitting volunteer work around other paid work in order to stay financially stable; others are involved in menial tasks and are alienated from school communities (Pollock, 2010; Pearce, forthcoming).

Perhaps by looking at Matthew's case, lessons can be learned that contribute to a solution. While finding meaningful, supportive volunteer opportunities may be a short-term solution for some; it may be worth considering the implications at the teacher education level. What Matthew has described is similar in some respects to an extended practicum, except that he has been given more control: he was able to choose the school and classroom teacher he worked with, the days he volunteered, and to some extent, the content of the experience. He has gained skills and knowledge that help him progress in his professional practice (Dreyfus \& Dreyfus, 1986). It is worth considering at the teacher education level how extended practicums, with more control and flexibility afforded to the teacher, can be constructed to build on the professional learning. Ideally, designing these kinds of practicums that transition more directly into paid employment would eliminate the need to volunteer and build professional learning.

In addition, there are broad considerations for human resource administrators beyond those in Ontario school boards. Given the instances of informal learning and tacit knowledge acquisition provided in this single case, it is clear that something more substantive may be occurring in such volunteer experiences than is traditionally assumed. Thus, volunteer activities of new teachers, and other professional groups where there is a significant volunteer population, should be explored with further rigor. Highly relevant instances of informal learning that may be taking place for a significant number of volunteers who are newly certified in their profession have not been sufficiently examined and quantified. Further investigation is needed, as there are implications, not only for unemployed teachers and school boards, but also for other professionals, organizations, unions, and human resource administrators. 


\section{Notes}

1. Full-time equivalent teachers.

2. Technological Studies teachers do not require a postsecondary degree, but they must have five years of paid experience and proof of competence in their specialty (such as a trade certificate) in addition to a secondary school diploma. They are certified to teach Technological Education for Grade 9 to 12.

3. As of January 2012, 55 of the 72 school boards in Ontario use Apply to Education (http://www.applytoeducation.com/) to post teaching jobs and recruit applicants (Apply to Education, n.d.).

4. Using the term "volunteer" in this case may be problematic for some readers as the degree of self-benefit in this situation may be considered high (Cnaan, Handy, \& Wadsworth, 1996). Regardless, in this investigation, the activities performed by unemployed teachers are generally undertaken as an act of free will, involve no remuneration, and have had a social benefit beyond the volunteer, to others in the school community such as teachers and students (Schugurensky \& Mundel, 2005).

5. The Ontario College of Teachers Act states that graduates of teacher certification programs in Ontario must have a "minimum of 40 days of practical experience in schools or in other situations approved by the College for observation and practice teaching" [s 1.2(2 v)]; at an average of 7 hours per day, this equates to about 280 hours. Matthew's program required him to complete 10 weeks of practice teaching, or about 350 hours. For comparison purposes, teacher candidates in Quebec must complete 700 hours (or 100 days) of practical experience in the classroom to be certified (Gouvernement du Québec, 2003); nearly two-and-ahalf times that of an Ontario graduate.

\section{References}

Apply to Education. (n.d.). School boards registered with applytoeducation. Retrieved January 27, 2012, from http://www.applytoeducation.com/Registration/AttRegis teredSchoolBoards.aspx
Cnaan, R. A., Handy, F., \& Wadsworth, M. (1996). Defining who is a volunteer: Conceptual and empirical considerations. Nonprofit and Voluntary Sector Quarterly, 25, 364383. 
Dreyfus, H.L., \& Dreyfus, S.E. (1986). Mind over machine: The power of human intuition and expertise in the era of the computer. Oxford: Basil Blackwell.

Duggleby, P. A. (2007). Real teachers: Real jobs. SubJournal, 8(1), 15-22.

Eraut, M. (2000). Non-formal learning and tacit knowledge in professional work. British Journal of Educational Psychology, 70, 113-136.

Gouvernement du Québec. (2003). Attracting, developing, and retaining effective teachers in Québec. Quebéc, Ministère de l'Éducation.

Ilsley, P.J. (1990). Enhancing the volunteer experience: New insights on strengthening volunteer participation, learning, and commitment. San Francisco: Jossey-Bass.

Livingstone, D.W. (2000). Researching expanded notions of learning and work and underemployment: Findings of the first Canadian survey of informal learning practices. International Review of Education, 46(6), 491-514.

Livingstone, D.W. (2001). Worker control as the missing link: Relations between paid/ unpaid work and work-related learning. Journal of Workplace Learning, 13(7/8), 308-317.

Livingstone, D.W. (2010). Job requirements and workers' learning: Formal gaps, informal closure, systemic limits. Journal of Education and Work, 21(3), 207-231.

Livingstone, D.W., Myles, J., Doray, P., Hubich, L., \& Collins, M. (2004). National survey of learning and work. Retrieved July 20, 2011, from http://wall.oise.utoronto.ca/ research/research_teams.htm

Mclntyre, F. (2011). Transition to teaching 2010: Determined new teachers face increased wait times. Professionally Speaking, (March), 30-34.
Ontario College of Teachers Act, R.S.O. 1996, Ontario Regulation 347/02. Retrieved March 20, 2012, from http://www.e-laws. gov.on.ca/html/regs/english/elaws_ regs_020347_e.htm

Ontario College of Teachers. (n.d.). Additional qualifications. Retrieved January 20, 2012, from http://www.oct.ca/additional_qual ifications/default.aspx?lang=en-CA

Ontario College of Teachers. (2011). Transition to Teaching 2010. Toronto, Ontario, Canada: Author.

Ontario Ministry of Education. (2011). Education facts. Retrieved January 20, 2012, from http://www.edu.gov.on.ca/eng/educa tionFacts.html

Pearce, J. (forthcoming). Volunteering in schools by newly certified, unemployed teachers: Sites of work and learning [working title]. (Masters thesis). The University of Western Ontario, London, Ontario.

Pollock, K. (2008). Occasional teachers' work engagement: Professional identity, workrelated learning and access to the profession and to daily work. (Doctoral dissertation). University of Toronto, Toronto, Ontario.

Pollock, K. (2010). Marginalization and the occasional teacher workforce in Ontario: The case of internationally educated teachers (IETs). Canadian Journal of Educational Administration and Policy, 100, pp. 1-21.

Schön, D. A. (1983). The reflective practitioner: how professionals think in action. New York: Basic Books.

Schugurensky, D., \& Mundel, K. (2005). Volunteer work and learning: Hidden dimensions of labour force training. In N. Bascia, A. Cumming, A. Datnow, K. Leithwood, and D. Livingstone (eds.), International Handbook of Educational Policy. (pp. 53-79). Manchester: Springer. 


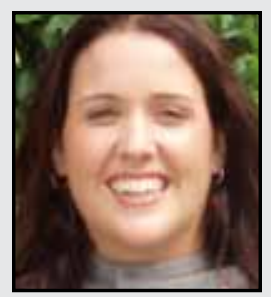

Jennifer Pearce is a Masters student in the Faculty of Education at Western University, London, Ontario. Prior to returning to school, she was a Volunteer Coordinator at a large nonprofit children's organization in an urban center, and sat on several local committees in the London area related to community volunteer work. Returning to school was motivated by a desire to lend a voice to volunteers and community organizations through research endeavours. Her research interests include volunteers, paid and unpaid work, formal and informal learning, and adult education. Beyond her Masters, she plans to continue her studies at the Ontario Institute for Studies in Education of the University of Toronto (OISE/UT).

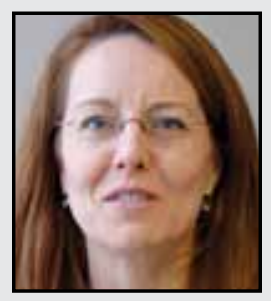

Katina Pollock is an Assistant Professor in the Faculty of Education at Western University, London, Ontario. She is also co-director of the Knowledge Network for Applied Educational Research (KNAER) for Ontario and Faculty Director of the Joint Master's Leadership Program with the Thames Valley District School Board. Her research interests include educational leadership and policy and contingent teacher workforces. Recent publications include "School Improvement: A Case of Competing Priorities!" (2012) and the forthcoming "Disrupting Myths of Poverty in the Face of Resistance." 